\title{
The influence of oceanographic conditions on the spatial and temporal patterns of Pleuronectiforms larvae (Teleostei) in the equatorial Atlantic Ocean
}

\author{
Paulo de Oliveira Mafalda Junior*, Andrei Tiego Cunha Cardoso, Christiane Sampaio de Souza
}

Departamento de Zoologia, Instituto de Biologia, Universidade Federal da Bahia

(Rua Ademar de Barros s/no, Laboratório de Plâncton Ondina, CEP: 40210-020, Salvador, BA, Brazil)

*Corresponding author: pomafa@ufba.br

\section{Abstract}

In this study, we analyzed the composition, distribution and abundance of Pleuronectiform larvae in relation to abiotic factors (temperature and salinity) and biotic factors (phytoplanktonic and zooplanktonic biomass) in the equatorial Atlantic Ocean. The working hypothesis was that the composition and distribution pattern of Pleuronectiform larvae species present differences between the areas studied according to the hydrographical environment/factors analyzed. Ichthyoplankton was collected during Period: 1 (August - October 1995), 2 (January - April 1997), 3 (April - July 1998) and 4 (September - December 2000), in the equatorial Atlantic Ocean. We examined 562 Bongo-net $(500 \mu \mathrm{m})$ samples that contained 719 Pleuronectiform larvae belonging to three families: Bothidae (Bothus ocellatus and Engyophrys senta), Paralichthyidae (Syacium papillosum, Citharichthys spilopterus and Citharichthys sp.) and Cynoglossidae (Symphurus sp.). The Pleuronectiform larvae accounted for $4 \%$ of total fish larvae and occurred at $37 \%$ of the oceanographic stations. B. ocellatus was the species with the highest relative abundance $(70 \%)$, the greatest value occurring during Period $3(77 \%)$, whereas the lowest relative abundance (57\%) was recorded in Period 1. S. papillosum was the species presenting the second highest relative abundance (14\%), with higher values during periods 1 and 4 . The results demonstrated that environmental factors influence the distribution and abundance of Pleuronectiform larvae so that each species occurs in a more favourable period and place for spawning and growth. B. ocellatus was related to warmer waters and greater phytoplanktonic and zooplanktonic biomass, while $S$. papillosum occurred in saltier waters and at lower temperatures.

Descriptors: Ichthyoplankton, Environmental variables, Distribution, Abundance.

http://dx.doi.org/10.1590/S1679-87592016111806402

\section{Resumo}

Neste trabalho analisamos a composição, distribuição e abundância das larvas Pleuronectiformes em relação aos fatores abióticos (temperatura e salinidade) e fatores bióticos (biomassa de fitoplâncton e zooplâncton) no Oceano Atlântico equatorial. A hipótese investigada foi que o padrão de composição e distribuição das espécies de larvas Pleuronectiformes apresenta diferenças entre as áreas estudadas de acordo com a hidrografia analisada. O ictioplâncton foi coletado nos Períodos: 1 (agosto - outubro 1995), 2 (janeiro - abril 1997), 3 (abril - julho 1998) e 4 (setembro - dezembro 2000), no Oceano Atlântico equatorial. Foram analisadas 562 amostras coletadas com rede Bongo $(500 \mu \mathrm{m})$ que continham 719 larvas de Pleuronectiformes pertencentes a 3 famílias: Bothidae (Bothus ocellatus e Engyophrys senta), Paralichthyidae (Syacium papillosum, Citharichthys spilopterus e Citharichthys sp.) e Cynoglossidae (Symphurus sp.). As larvas de Pleuronectiformes representaram $4 \%$ do total de larvas de peixes e ocorreram em $37 \%$ das estações oceanográficas. $B$. ocellatus foi a espécie mais abundante $(77 \%)$, com maior valor observado no Período 3 (77\%) e menor no Período $1(57 \%)$. S. papillosum foi a segunda espécie com maiores valores de abundância relativa (14\%), registrados nos Períodos 1 e 4. Os resultados demonstraram que os fatores ambientais tendem a influenciar a distribuição e abundância de larvas de Pleuronectifomes, conduzindo as diferentes espécies a um período e local mais favorável para desova e crescimento. B. ocellatus esteve relacionada com águas mais quentes e com maior concentração de biomassa fitoplanctônica e zooplanctônica, enquanto S. papillosum ocorreu em águas salinas e de menores temperaturas.

Descritores: Ictioplâncton, Variáveis ambientais, Distribuição, Abundância. 


\section{INTRODUCTION}

The fishes of the Pleuronectiform order inhabit benthonic environments in tropical, subtropical and polar regions (NELSON, 2006). This is a large order consisting of 14 families, 134 genera and 678 species (BONECKER et al., 2006). Nineteen species of Paralychytidae larvae have been identified in Brazilian marine waters: 12 species of Bothidae and 12 species of Cynoglossidae larvae (BONECKER; CASTRO, 2006; BONECKER et al., 2006).

The Pleuronectiform fishes are important in commercial fisheries and they are popularly called "flounder", "halibut", "sole", "place" and "turbot" (NELSON, 2006). Larval flatfishes have an eye on each side of the head, but during a period of rapid body change (metamorphosis) one eye migrates to the other side of the head, after which the larvae settle to the bottom (LYCZKOWSKISHULTZ; BOND, 2006). The planktonic eggs and larvae are found primarily in the upper few meters of the water column (MOSER; SUMIDA, 1996), and are among the abundant ichthyoplankton taxa collected during pelagic fish larvae trawls in Brazilian coastal waters (NONAKA et al., 2000; CASTRO et al., 2005; MAFALDA JÚNIOR et al., 2008; KATSURAGAWA et al., 2011). In Todos os Santos Bay, Achirus lineatus and Trinectes paulistanus have been found in the coastal area subject to the influence of petrochemical activities (MAFALDA JÚNIOR et al., 2008; KATSURAGAWA et al., 2011). This order is represented by 5 families (Achiridae, Bothidae, Cynoglossidae, Paralichthyidae and Pleuronectidae) which together consist of at least 56 species (MENEZES et al., 2003). Despite the high richness little is known of the larval abundance, distribution patterns or reproductive periods of the Pleuronectiforms in the oceanic waters of northeastern Brazil (MAFALDA JÚNIOR; SOUZA, 2009a).

Four tongue fishes of the Genus Symphurus (KURTZ; MATSUURA, 1994) and larvae of Bothus ocellatus and Bothus lunatus (MACEDO-SOARES et al., 2014) have been identified in the oceanic waters of Southern Brazil. In the Brazilian central oceanic region larvae of Bothus ocellatus and Syacium papillosum have been the most captured (BONECKER; CASTRO, 2006). According to MAFALDA JÚNIOR and SOUZA (2009b), Pleuronectifom fish larvae were abundant in the Fernando de Noronha archipelago in the northeastern Brazilian oceanic area. Recent ichthyoneuston studies have demonstrated the occurrence of larvae of Bothidae and Paralichthydae in the Saint Peter and Saint Paul archipelago and the Fernando de Noronha chain (VASKEJÚNIOR et al., 2005; LESSA et al., 2009).

A study of the distribution patterns of fish larvae contributes to an understanding of the interrelationships among fish species during their early life stages, as well as to an understanding of adult spawning patterns (NONAKA et al., 2000), but little is known about the majority of Pleuronectiform species.

In this study, we have analyzed the composition, distribution and abundance of Pleuronectiform larvae in relation to abiotic factors (temperature and salinity) and biotic factors (phytoplanktonic and zooplanktonic biomass) in the equatorial Atlantic Ocean. The working hypothesis was that the composition and distribution pattern of Pleuronectiform larvae species present differences as between the areas studied according to the hydrographical environment/factors analyzed.

\section{STUdy AREA}

The study area, in the equatorial Atlantic Ocean, is limited by the estuary of the Parnaíba river (Piauí), and Todos os Santos bay, in Salvador (Bahia) (Figure 1), and includes the Archipelagos of Fernando de Noronha and Saint Peter and Saint Paul. St. Paul's Rocks are a very small group of rocky islands located on the mid-Atlantic Ridge, just north of the Equator (FEITOSA et al., 2003), 510 nautical miles from the Brazilian coast (CAMPOS et al., 1995). It is one of smallest, most isolated groups of oceanic islands in the world (FEITOSA et al., 2003).

This is tropical oceanic region, constituting an oligothrophic system that possess a complex alimentary web with low biological productivity (EKAU; KNOPPERS, 1999). The South Equatorial Current (SEC) reaches the NE Brazilian shelf between 11 and $15^{\circ} \mathrm{S}$ (PETERSON; STRAMMA, 1991). The SEC consists of a broad westward flow with a mean velocity of 10 to $15 \mathrm{~cm} \cdot \mathrm{s}^{-1}$ - though along the Equator there is a much swifter current with a mean velocity of $30 \mathrm{~cm} \cdot \mathrm{s}^{-1}$ (TCHERNIA, 1980). The North Brazil Current follows at a mean velocity of 75 $\mathrm{cm} . \mathrm{s}^{-1}$ with a surface temperature of between 28 and $30^{\circ} \mathrm{C}$, and superficial salinity between 35 and 37 (MEDEIROS et al., 1999). The Brazil Current flows at a mean velocity of 10 to $15 \mathrm{~cm} \cdot \mathrm{s}^{-1}$ with a mean surface temperature of $26^{\circ} \mathrm{C}$ and salinity of above 35 (TCHERNIA, 1980).

The Tropical Water (TW) which is part of the southward flowing Brazil Current, has been characterized as having 


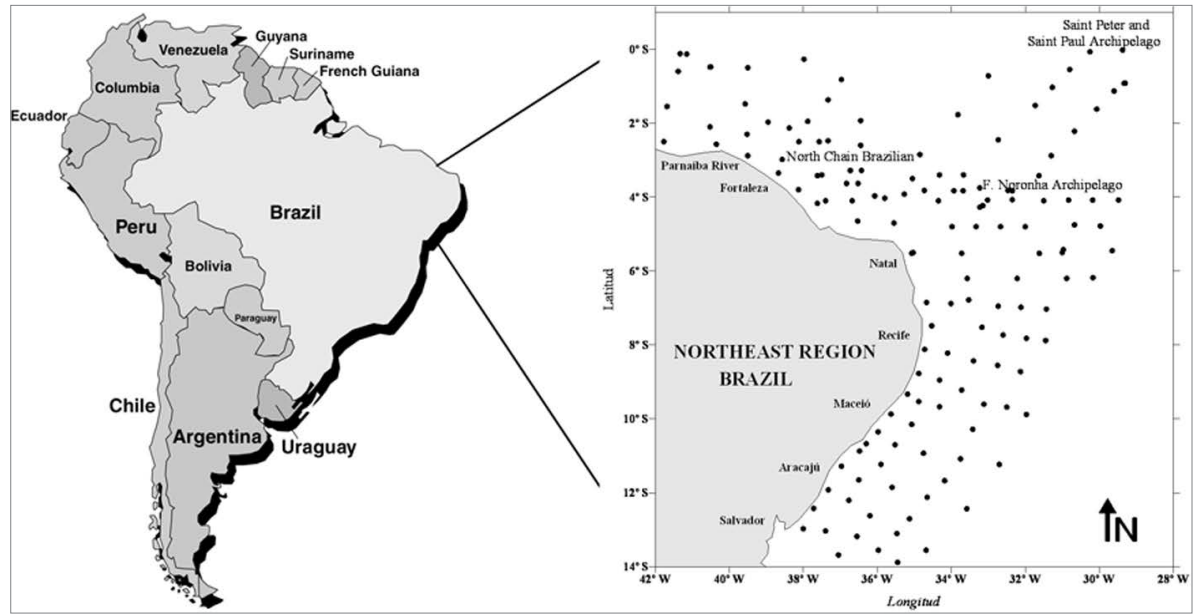

Figure 1. Study area showing the sampling stations in the equatorial Atlantic Ocean.

salinity $>36$ and temperature $>20^{\circ} \mathrm{C}(\mathrm{CAMPOS} v ., 1995$; STRAMMA; SCHOT, 1999). Below the Tropical Water, the South Atlantic Central Water (SACW) had salinity levels ranging from 34.5 to 36 and temperatures between 5 and $20^{\circ} \mathrm{C}$ (SILVEIRA et al., 2000; STRAMMA; SCHOT, 1999).

\section{MATERIAL AND METHODS}

\section{SAMPLING}

A total of 562 samples were collected during four REVIZEE expeditions undertaken in the equatorial Atlantic Ocean between 1995 and 2000, in each period of which the sampling sites were similarly situated (Figure 1). The expeditions were carried out in August - October 1995 (Period 1 - winter), January - April 1997 (Period 2 - summer), April - July 1998 (Period 3 - spring) and September - December 2000 (Period 4 - autumn). The ichthyoplankton sampling was done with Bongo nets (50 $\mathrm{cm}$ in diameter at the mouth, 300 and $500 \mu \mathrm{m}$ meshes). The nets were equipped with two independent flowmeters to estimate the water volume filtered. Only the 562 Bongonet $(500 \mu \mathrm{m})$ samples were examined.

The sampling method used followed SMITH and RICHARDSON'S (1977). Sampling was done by means of oblique hauls from the maximum depth of $200 \mathrm{~m}$ to the surface. The duration of the tow was 10 minutes. The samples obtained were preserved in $4 \%$ buffered formalin - seawater. All Pleuronectiform larvae were removed from each sample and stored in $70 \%$ alcohol. The Pleuronectiform larvae were identified to the lowest taxonomic level according to the morphological characters of each group (FAROOQI et al., 2006; LARA, 2006; LYCZKOWSKI-SHULTZ; BOND, 2006; MACEDO; MONTEIRO-RIBAS, 2006).

Standard densities of individual taxa were expressed as the number of specimens per $100 \mathrm{~m}^{3}$ of water filtered for each collection. All the larvae identified were deposited in the larval fish collection of the Plankton Laboratory of the Federal University of Bahia, Salvador, Brazil.

Water temperature and salinity were measured at each station using a CTD. Water samples for the determination of phytoplanktonic biomass (chlorophyll $a$ ) in $1 \%$ of light were obtained using a fluorescence sonde. The determination of the zooplanktonic biomass (dry weight) was carried out in accordance with OMORI and IKEDA'S methodology (1984).

\section{DATA ANALYSIS}

In order to determine the statistical significance of the temporal variability of biotic and abiotic factors, Kruskal-Wallis's non parametric test and Dunn's multiple comparisons test (ZAR, 1984) were used. Detrended Canonical Correspondence Analysis (DCCA) was performed with all the oceanographic variables to investigate the gradient length. Since the gradient was below 3, Redundancy Analysis (RDA) was employed (LEPS; SMILAUER, 2003) to verify the Pleuronectiforms' pattern of variation associated with the abiotic and biotic variables (temperature, salinity, phytoplanktonic biomass and zooplanktonic biomass). Prior to analysis, logarithmic transformation $\mathrm{Ln}(\mathrm{x}+1)$ of larval density (x) was performed to determine the most comparable data. The matrix created with the oceanographic data 
was submitted to a square root transformation to reduce the effect of different scales. The criterion adopted for the determination of characteristic species was a relative abundance greater than $3 \%$.

\section{RESULTS}

\section{OCEANOGRAPHIC CHARACTERISTICS}

The distribution patterns of the oceanographic variables were based on values measured at the surface. The temperature showed variations of up to $1.5^{\circ} \mathrm{C}$ between periods 1 and 2 . There were significant differences in temperature between the four periods analyzed (KruskalWallis $=0.0001)$. Dunn's multiple comparisons test showed that periods 1 and 4 differ from periods 2 and 3. The salinity was also significantly different between the periods (Kruskal-Wallis $=0.0001$ ). Dunn's multiple comparisons test showed that periods 1 and 2 differ from periods 3 and 4 . The values of salinity and temperature registered in all the periods indicated the presence of Superficial Equatorial Water (SEW) which had a salinity $>36$ and temperature $>26^{\circ} \mathrm{C}$ (SILVEIRA et al., 2000), and Coastal Water $(\mathrm{CW})$, with salinity of around 35 .

\section{PhytoplankTONiC AND ZoOplankTONIC BIOMASS}

The phytoplanktonic and zooplanktonic biomass was significantly different between the periods (KruskalWallis $=0.0001)$. The lowest primary biomass was found in period 1 and the highest values were observed in periods 3 and 4 (Dunn's test $=0.05$ ). The dry weight also presented the lowest values during Period 1 but the highest were found in Periods 2 and 3 (Dunn's test $=0.05$ ).

\section{LARVAL FISH COMPOSITION}

A total of 719 larvae, represented by: Bothidae (Bothus ocellatus and Engyophrys senta), Paralichthyidae (Syacium papillosum, Citharichthys spilopterus and Citharichthys sp.) and Cynoglossidae (Symphurus sp.) were identified in the equatorial Atlantic. Among the total of Teleostei fish larvae, the Pleuronectiforms had low relative abundance $(4 \%)$ and frequency of occurrence $(37 \%)$

The following characteristic species accounted for $92 \%$ of the total relative abundance: Bothus ocellatus (77\%), Syacium papillosum (14\%) and Engyophrys senta (8\%) (Figure 2). B. ocellatus showed the highest abundance during Period 2, corresponding to $32 \%$ of the total larvae identified (Figure 2), while period 4 was that of the lowest abundance, with 7\% of the total (Figure 2). $S$. papillosum was the second most abundant species, accounting for $14 \%$ of the total of Pleuronectiforms. This species presented its greatest abundance during periods 1 and 2 (Figure 2). The third most abundant species was E. senta that corresponded to $8 \%$ of the Pleuronectiform larvae. Citharichthys spilopterus, Citharichthys sp. and Symphurus sp. were less abundant, contributing with $8 \%$ of the total larvae (Figure 2).

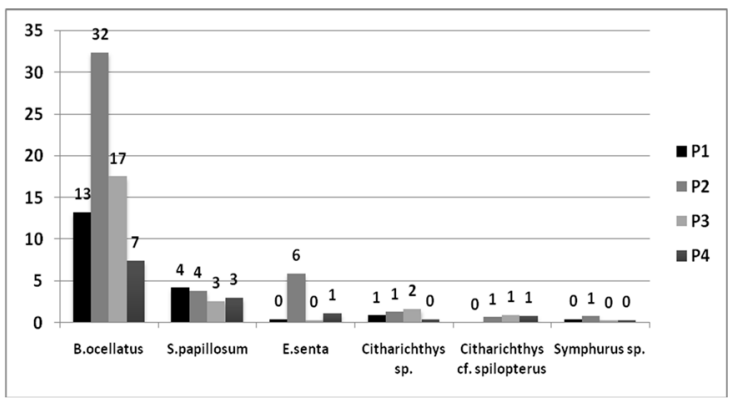

Figure 2. Relative percentual abundance of Pleuronectiform larvae in the equatorial Atlantic Ocean, by period of collection (P - Period).

\section{SPATIAL AND TEMPORAL DISTRIBUTION}

Pleuronectiform larvae were collected more frequently within the oceanic zone of the equatorial Atlantic around seamounts and oceanic islands. Bothus ocellatus was widely distributed in the neritic and oceanic region and was collected in all the periods presenting its maximum density during periods 1, 2 and 3 in the Saint Peter and Saint Paul Archipelago, the Fernando de Noronha Archipelago and the North Brazilian Chain (Figure 3). S. papillosum presented wide distribution in the oceanic zone and was also collected in all the periods, its maximum density occurring during period 1 in the Fernando de Noronha Archipelago and North Brazilian Chain (Figure 4). E. Senta was found predominantly at the oceanic stations and its highest density occurred near the Fernando de Noronha Archipelago during period 2 (Figure 4). C.spilopterus, Citharichthys sp. and Symphurus sp. occurred mainly at the oceanic stations, between the Fernando de Noronha Archipelago and the North Brazilian Chain, during period 3 and off Aracajú during period 4 (Figure 5).

\section{DATA ANALYSIS}

Redundancy Analysis, based on a reduced set of four environmental variables (temperature, salinity, phytoplanktonic biomass and zooplanktonic biomass), 


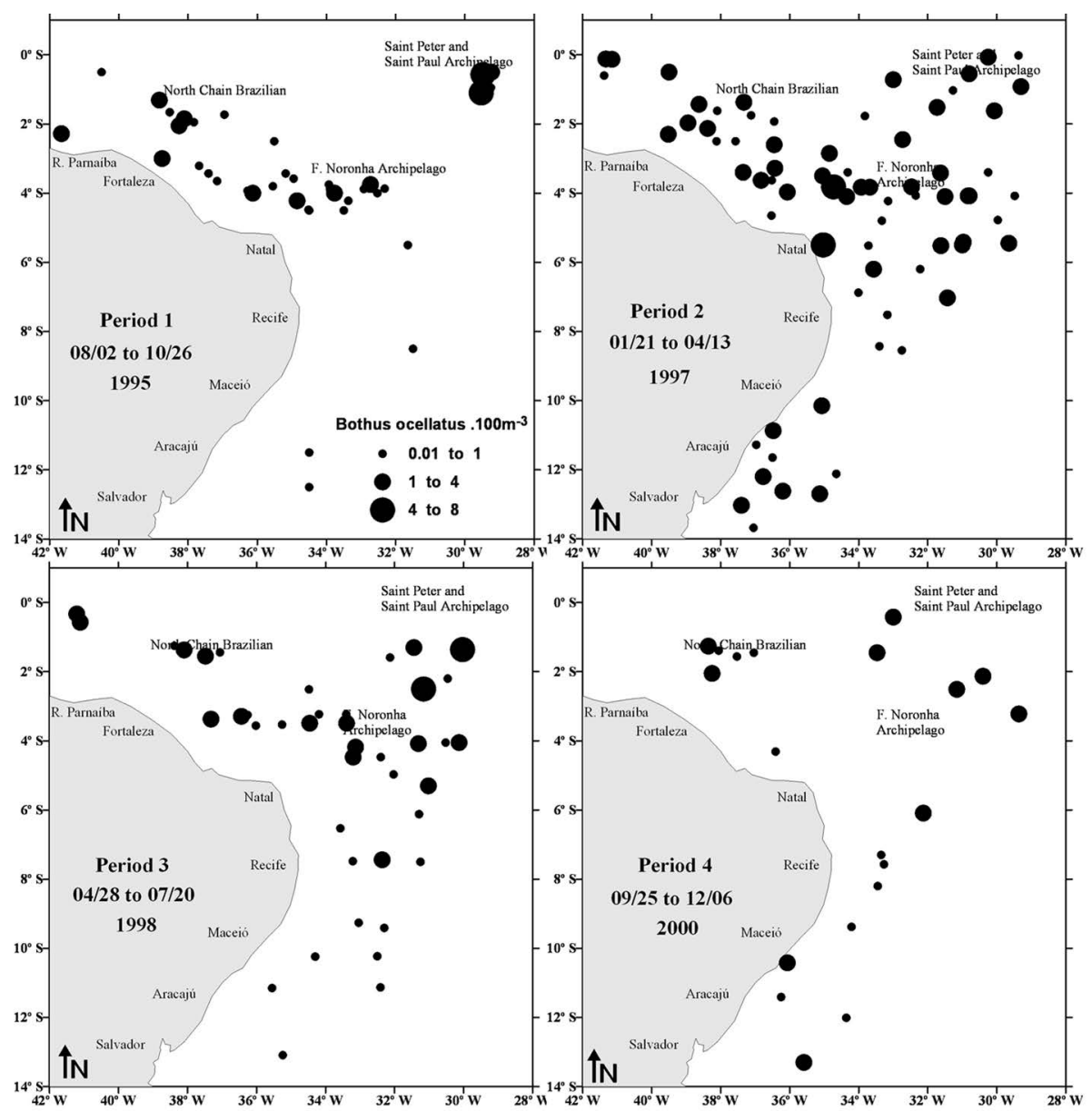

Figure 3. Temporal and spatial distribution of Bothus ocellatus larvae in the equatorial Atlantic Ocean.

was performed to ascertain the existence of an ordination between the species and their respective samples. Eigenvalues, measurements of importance for RDA axes that may vary between zero and one, ranged from 0.033 for RDA 1 to 0.372 for RDA 4. Species-environment correlations were high for the two first RDA axes, ranging from 0.319 for RDA 1 to 0.256 for RDA 2. The cumulative percentage of species variance (CPSV) accounted for a total of $43 \%$ of the RDA on the first four RDA axes. Further, the first two RDA axes explained $98 \%$ of the cumulative percentage of the species-environment (CPSE). Because the first two RDA axes explained 5\% of the CPSV and 98\% of the CPSE, the latter two RDA axes were not further interpreted. The Monte Carlo test was significant for the first RDA axis $(p=0.02)$ and all the RDA axes $(p=0.006)$.

The low multiple regression coefficients of environmental variables indicated that there were no collinear variables. This result is important because multicolinear variables must be deleted from the analysis, since collinear variables can influence the canonical coefficients (TER BRAAK, 1986). The plot of RDA sample and species scores illustrates their dispersion pattern, and the plot of environmental variable vectors illustrates the directions and strengths of environmental relationships within the first two dimensions of the RDA ordination (Figure 6).

The environmental gradients were important correlates with the abundance of Pleuronectiform larvae in the RDA. The temperature and salinity were correlated with RDA axis 1 and the phytoplanktonic biomass and zooplaktonic biomass correlated with RDA axis 2 . These environmental gradients also reflected the spatial and temporal changes in the species density. $B$. ocellatus was negatively correlated with the second axis and positively correlated with the first RDA axis. E. senta was positively correlated with the first and second RDA axes. S. papillosum was negatively correlated with the first axis and positively correlated with the second RDA axis. 


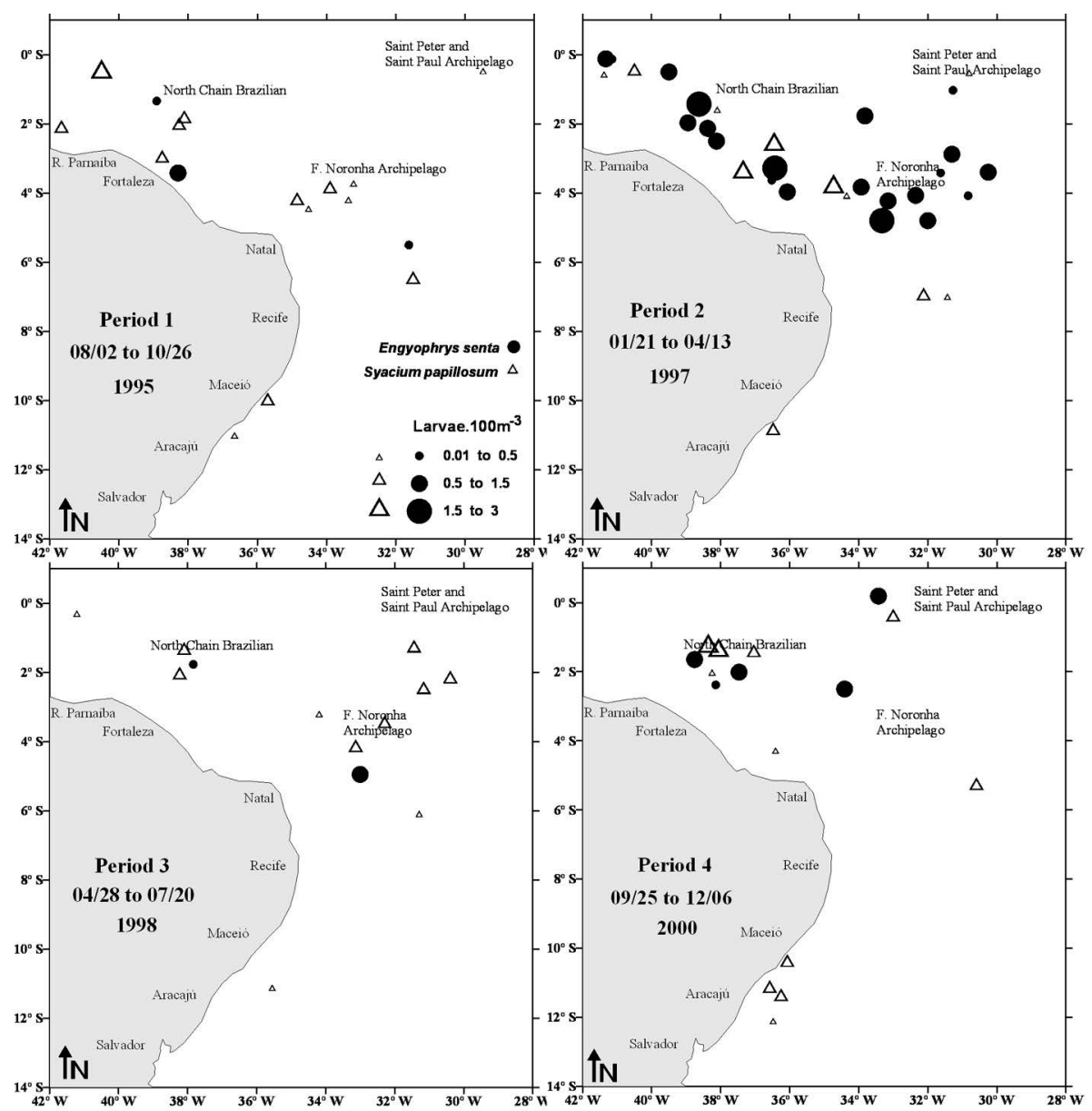

Figure 4. Temporal and spatial distribution of Engyophrys senta and Syacium papillosum larvae in the equatorial Atlantic Ocean.

This implies that $B$. ocellatus and E. senta occurred mainly at high water temperature and phytoplanktonic and zooplanktonic biomass during Periods 2 (summer) and 3 (spring). S. papillosum appeared during all periods at high salinity, low water temperature and low planktonic biomass (Figure 6).

\section{DISCUSSION}

According to the data obtained in this study and in the literature (MEDEIROS et al., 1999) two water masses are dominant in this area: Tropical Water (TW) and South Atlantic Central Water (SACW). Coastal water was also observed at some stations during all periods, but the Tetraodontiform fish larvae were captured only in Tropical Water. The Tropical water occupies the top layer with the greatest thickness in the southern oceanic region and least thickness in the SPSP archipelago (MEDEIROS et al., 2009). Based upon surface temperature and salinity results the study area presented typical characteristics of equatorial regions, with high salinity and temperature. The horizontal distribution of the salinity showed high values in the North Brazilian Chain and Fernando de Noronha Chain and low values in the Saint Peter and Saint Paul Archipelago (SOUZA et al., 2013).

Consequently this area is known to be oligotrophic with a low concentration of nutrients and phytoplanktonic and zooplanktonic biomass (EKAU; KNOPPERS, 1999; MEDEIROS et al., 1999; NEUMANN-LEITÃO et al., 1999). Such characteristics may be explained by the existence of a warm surface layer above a colder and denser sub-surface layer, which creates a permanent thermocline. This tends to inhibit the upward nutrient flow from rich deeper layers, restricting primary production in surface waters (TRAVASSOS et al., 1999).

In the equatorial Atlantic Ocean, there are three areas where submarine relief and local current may facilitate the upwelling process. These include the Saint Peter and 


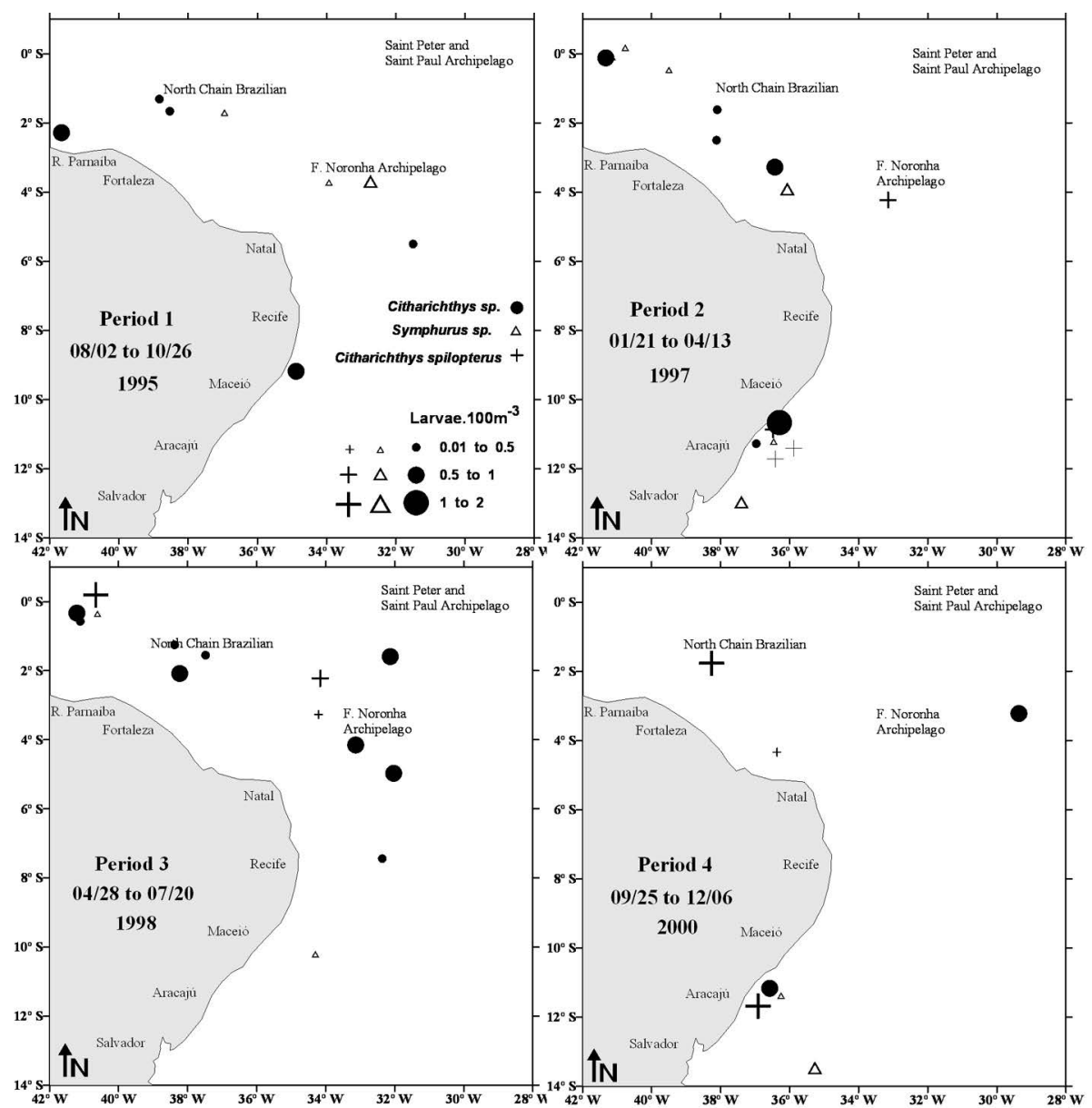

Figure 5. Temporal and spatial distribution of Citharichthys spilopterus, Citharichthys sp. and Symphurus sp. larvae in the equatorial Atlantic Ocean.

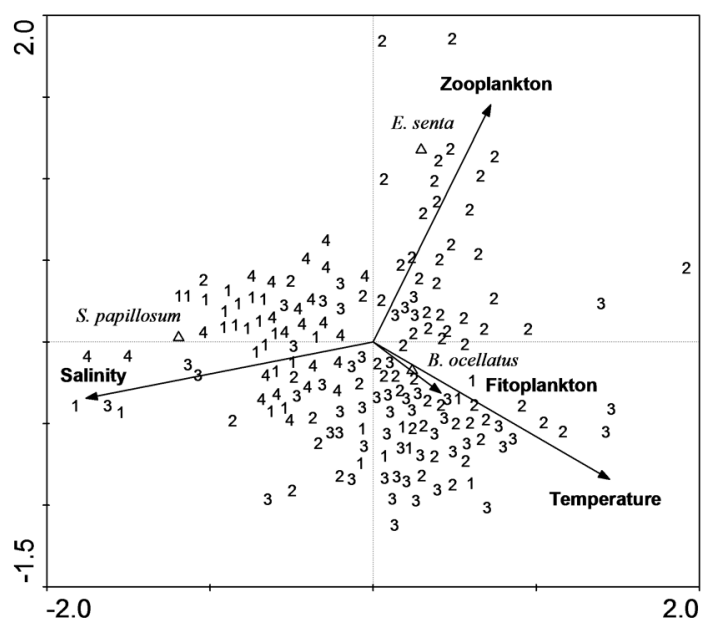

Figure 6. Ordination diagram of the Redundancy Analysis (RDA) with sampling stations, characteristic species and oceanographic conditions (1: Period 1; 2: Period 2; 3: Period 3; 4: Period 4; Clorofila: phytoplanktonic biomass; Tem: temperature; Sal: salinity; Zooplankton: zooplanktonic biomass).
Saint Paul Archipelago, the Fernando de Noronha Chain and the North Brazilian Chain. At one seamount in the North Brazilian Chain, a pronounced upwelling cone was found, suggesting the formation of a Taylor column that presented the greatest potential for enrichment of the surface layers, but there was no evidence to show that any of the upwelling extended to the surface (TRAVASSOS et al., 1999).

SOUZA et al. (2013) studied the enrichment processes originating in deeper waters. They found evidence of upwelling reaching into the mixed layer and into the euphotic zone, with the mixed layer reaching a depth of $50 \mathrm{~m}$. The highest abundances of chlorophyll a coincided with stations where upwelling was recorded by the authors. In the four periods investigated, the values of phytoplanktonic and zooplanktonic biomass tended to increase in the areas adjacent to the North Brazilian Chain, the Saint Peter and Saint Paul Archipelago and the 
Fernando de Noronha Archipelago, possibly owing to the topographic upwelling (SOUZA et al., 2013). In this study Pleuronectiform larvae were collected more frequently around seamounts and oceanic islands. In the Fernando de Noronha chain $29 \%$ of fish larvae collected in neuston were Pleuronectiform larvae (LESSA et al., 2009).

The low abundances of mesozooplankton generally correspond to oligotrophic water masses and differences were locally affected by mangrove areas inshore or by topographic upwelling offshore (NEUMANN-LEITÃO et al., 1999). In period 1 (winter) the lowest values for the occurrence and density of ichthyoplankton (MAFALDA JÚNIOR et al., 2009a) were recorded, which may have happened because of the oligotrophic water conditions in the period represented by the low values of phytoplankton biomass $\left(0.15 \mu \mathrm{g} . \mathrm{L}^{-1}\right)$ compared to those of other periods.

The Pleuronectiform larvae in the equatorial Atlantic Ocean originated from a diverse collection of demersal fishes represented by 3 families, 4 species and two morphotypes. The Pleuronectiforms are an order composed of 11 families (NELSON, 2006), three of them captured in the present study. The richness of 6 morphotypes is characteristic of the tropical marine ecosystem and similar taxonomic richness of larval fish has been found in the Brazilian Tropical ocean where 3 families and 13 species have been identified (BONECKER et al., (In Press); BONECKER et al., 2006; MACEDO-SOARES; MONTEIRO-RIBAS, 2006). In the southern Gulf of Mexico 15 species of Pleuronectiform larvae have been identified and most of the species occurred throughout the year but were most abundant in springsummer (FLORES-COTO et al., 1991).

MACEDO-SOARES and MONTEIRO-RIBAS (2006) found three families of Pleuronectiforms in the Brazilian Central Exclusive Economic Zone, all of them occurring in the present study though only three species match with species found in the equatorial Atlantic Ocean (Bothus ocellatus, Engyophrys senta and Syacium papillosum). The occurrence of Pleuronectiform fish larvae should be a temporal sequence resulting from each species' distribution and its spawning period, known for most of the species.

Three Pleuronectiform species predominated in the area surveyed: Bothus ocellatus (77\%), Syacium papillosum (14\%) and Engyophrys senta (8\%). In the Brazilian Tropical Atlantic B.ocellatus and S.papillosum were also the most abundant species (BONECKER; CASTRO, 2006). B.ocellatus and S.papillosum are marine species associated with coral reefs and E.senta is a demersal species (MACEDO-SOARES; MONTEIRO-RIBAS, 2006). There is no detailed information about the reproductive cycle of pleuronectiforms in the equatorial Atlantic Ocean but we can speculate that adults spawn around seamounts and oceanic islands and eggs and larvae are transported to deeper waters. The distribution of Pleuronectiform larvae in the equatorial Atlantic has varied over time and between sampling locations. As observed for Tetraodontiform larvae (NOGUEIRA et al., 2012), the wide larval distribution of this taxa at open ocean stations might be a consequence of a high larval drift from the seamounts and coral-reef area where massive spawning occurs. In the Gulf of California the highest concentration of Syacium ovale larvae were also found around great islands (ACEVES-MEDINA et al., 2003).

Most of the stations with Pleuronectiform larvae were concentrated in periods 2 (summer) and 3 (spring), with $68 \%$ of larvae and characterized by higher temperature values, as well as greater primary and secondary biomass. The group formed in these periods presented higher secondary productivity also showing a helpful larval habitat with high food availability (HEATH, 1992). In the Gulf of Mexico (FLORES-COTO et al., 1989), the Mediterranean Sea (SABATÉS, 1990) and the Gulf of Cádiz (MAFALDA JÚNIOR; RUBÍN, 2006), the high abundance of fish larvae suggests that the summer also coincides with the onset of the reproductive season of many fish species. The periods 1 (winter) and 4 (autumn), characterized by higher salinity values and the lowest values of temperature and primary and secondary biomass, showed a lower occurrence of larvae. However, Pleuronectiform fish larvae have always been captured in Tropical Water that presents high temperature and salinity values (CAMPOS et al., 1995; STRAMMA; SCHOT, 1999). Oblique bongo tows are integrative of the entire water column $(0-200 \mathrm{~m})$, so it is not possible to determine the depth or the temperature at which the larvae were found (ACEVES-MEDINA et al., 2006).

Larvae of B.ocellatus occurred year-round but were most abundant in spring-summer with high phytoplanktonic and zooplanktonic biomass. In the western Tropical Atlantic B.ocellatus was the most abundant species, being found in winter, summer and spring (BONECKER; CASTRO, 2006). In the Gulf of California Bothus leopardinus larvae increase in abundance during the summer months (ACEVES-MEDINA et al., 2003).

E.senta larvae were concentrated in periods 2 (summer) and 3 (spring), with high phytoplanktonic and zooplanktonic biomass. Great abundances of Engyophrys senta larvae have also been recorded in spring-summer on 
the outer shelf and in the oceanic area of the southern Gulf of Mexico (FLORES-COTO et al., 1991), but in the western Tropical Atlantic E.senta larvae have only been found in the winter (BONECKER; CASTRO, 2006).

Larvae of Syacium papillosum have been found practically all year round in tropical waters with low plankton biomass. S.papillosum too was the second most abundant species, being found in winter, summer and spring in the western Tropical Atlantic (BONECKER; CASTRO, 2006). In the Eastern Tropical Pacific Syacium ovale larvae are most abundant in summer and although they were present during winter, their abundance was low (AHLSTROM, 1972; MOSER et al., 1994). In the Gulf of California Syacium ovale larvae can be present during spring and fall, but the maximum reproductive activity occurs in the summer, as is suggested by the highest larval abundance in Tropical Waters with low plankton biomass (ACEVES-MEDINA et al., 2003).

Pleuronectiform flatfish distribution in the environment is influenced by salinity and varies among species and with development stage (SCHREIBER, 2001). SAMPAIO et al. (2007) have demonstrated in the laboratory the need for highly saline water for the successful reproduction and incubation of Brazilian flounder eggs (Paralichthys orbignyanus).

Although adult pleuronectiform species are benthic organisms, the eggs and larvae are pelagic (FAROOQI et al., 2006; LARA, 2006; LYCZKOWSKI-SHULTZ; BOND, 2006; MACEDO; MONTEIRO-RIBAS, 2006). These flatfish are frequently collected, from their early stages, in ichthyoplankton surveys, their seasonal occurrences allowing us to make indirect assumptions concerning spawning periods and locations (ACEVESMEDINA et al., 2006). Moreover, the tropical affinity of these species suggests a strong dependence of the spawn on tropical water mainly during summer and spring where pleuronectiform larvae have been collected with greater frequency around seamounts and oceanic islands.

\section{ACKNOWLEDGEMENTS}

The authors express their thanks to the Interministerial Commission for Marine Resources (SECIRM), the Ministry of the Environment (MMA), the Sectorial Plan for Marine Resources, the Direction of Hydrography and Navigation and ANTARES oceanographic ship, for supporting this study through the REVIZEE program.

\section{REFERENCES}

ACEVES-MEDINA， G.; SALDIERNA-MARTÍNEZ， R. J.; GONZÁLEZ, E. A. Distribution and abundance of Syacium ovale larvae (Pleuronectiformes: Paralichthyidae) in the Gulf of California. Rev. Biol. Trop., v. 51, n. 2, p. 561-570, 2003.

AHLSTROM, E. H. Kinds and abundance of fish larvae in the Eastern Tropical Pacific on the second multi-vessel EASTROPAC survey and observations on the annual cycle of larval abundance. Fish. Bull., v. 70, n. 4, p. 1153-1242, 1972.

BONECKER, A. C. T.; CASTRO, M. C. Atlas de larvas de peixes da região central da Zona Econômica Exclusiva brasileira. Série Livros/Documentos REVIZEE Score Central. Rio de Janeiro: Museu nacional, 2006. $214 \mathrm{p}$

BONECKER, A. C. T.; CASTRO, M. S.; NAMIKI, C.; BONECKER, F. T.; BARROS, F. B. A. G.; MONTEIRORIBAS, W. M. Ictioplâncton. In: VALENTIN, J. L. (Ed.). Características hidrobiológicas da região central da Zona Econômica Exclusiva brasileira (Salvador, BA, ao Cabo de São Tomé, RJ). Brasília: Ideal gráfica e Editora, 2006. 216 p.

CAMPOS, E. J. D.; GONÇALVES, J. E.; IKEDA, Y. Water mass characteristics and geostrophic circulation in the South Brazil Bight: summer of 1991. J. Geophys. Res., v. 100, n. C9, p. 18537-18550, 1995.

CASTRO, M. S.; BONECKER, A. C. T.; VALENTIN, J. L. Seasonal Variation in Fish Larvae at the Entrance of Guanabara Bay, Brazil. Braz. Arch. Biol. Technol., v. 48, n. 1, p. 121-128, 2005.

EKAU, W.; KNOPPERS, B. An introduction to the pelagic system of the north-east and east Brazilian shelf. Arch. Fish. Mar. Res., v. 47, p. 113-132, 1999.

EKAU, W.; WESTHAUS-EKAU, P.; MEDEIROS, C. Large scale distribution of fish larvae in the continental shelf waters off North-East Brazil. Arch. Fish. Mar. Res., v. 47, p. 183 200, 1999.

FAROOQI, T. W.; SHAW, R. F.; DITTY, J. G.; LYCZKOWSKISHULTZ, J. CYNOGLOSSIDAE: Tongue fishes. In: RICHARDS, W. J. (Ed.). Early Stages of Atlantic Fishes: An Identification Guide for the Western Central North Atlantic. Boca Ratón: CRC Press/Taylor \& Francis Group, 2005. p. 2367-2379.

FEITOZA, B. M.; ROCHA, L. A.; LUIZ-JÚNIOR, O. J.; FLOETER, S. R.; GASPARINI, J. L. Reef fishes of St. Paul's Rocks: new records and notes on biology and zoogeography. Aqua, v. 7, p. 2, p. 61-82, 2003.

FLORES-COTO, C.; ABUNDIO-LÓPEZ, F.; ZAVALAGARCÍA, F. Larval distribution and abundance of pleuronectiformes from the southern gulf of Mexico. Estuarine. Coast. Shelf Sci., v. 32, n. 5, p. 439-450, 1991.

GERARDO ACEVES-MEDINA, RICARDO J. SALDIERNAMARTÍNEZ AND ENRIQUE A. GONZÁLEZ-NAVARRO. Distribution and abundance by larval developmental stages of Symphurus williamsi (Pleuronectiformes: Cynoglossidae) in the Gulf of California. Sci. Mar. 70(2): 291-302. 2006.

HEATH, M. R. (1992), Field investigations of the early life stages of marine fish. Adv. Mar. Biol., 28, 174.

KATSURAGAWA, M.; ZANI-TEIXEIRA, M. L.; GOÇALO, C. G.; OHKAWARA, M. H.; ITAGAKI, M. K. Ichthyoplankton distribution and abundance in the northern Todos os Santos and Camamu Bays, Bahia State-Brazil. Braz. J. Oceanogr., v. 59, n. 1, p. 97-109, 2011. 
KURTZ, F. W.; MATSUURA, Y. Early Development of Four Tonguefishes of the Genus Symphurus (Osteichthyes: Cynoglossidae) from the Southern Brazil. Japan J. Ichthyol., v. 41, p. 2, p. 141-148, 1994.

LARA, M. R. BOTHIDAE: Lefteye flounders. In: RICHARDS, W. J. (Ed.). Early Stages of Atlantic Fishes: An Identification Guide for the Western Central North Atlantic. Boca Ratón: CRC Press/Taylor \& Francis Group, 2005. p. 2327-2344.

LEPS, J.; SMILAUER, P. Multivariate analysis of ecological data using CANOCO. Cambridge: Cambridge University Press, 2003. 269 p.

LESSA, R.; BEZERRA JÚNIOR, J. L.; NASCIMENTO, E. D.; LIMA, M.; PEREIRA, A. A. Oceanografia Biológica: Composição, distribuição e abundância do ictioneuston na ZEE da Região Nordeste do Nordeste do Brasil. In: HAZIN, F. H. V. (Ed.). Coleção Programa revizee score nordeste. Fortaleza: Martins \& Cordeiro, 2009. 234 p.

LYCZKOWSKI-SHULTZ, J.; BOND, P. J. PARALICHTHYIDAE: Sand flounders. In: RICHARDS, W. J. (Ed.). Early Stages of Atlantic Fishes: An Identification Guide for the Western Central North Atlantic. Boca Ratón: CRC Press/ Taylor \& Francis Group, 2005. p. 2291-2325.

MACEDO, A. P. S.; MONTEIRO-RIBAS, W. M. Pleuronectiformes. In: BONECKER, A. C. T.; CASTRO, M. S. (Eds.). Atlas de larvas de peixes da região central da zona econômica exclusiva brasileira. Rio de Janeiro: Museu Nacional, 2006. p. 176-190.

MACEDO-SOARES, L. C. P.; GARCIA, C. A. E.; FREIRE, A. S.; MUELBERT, J. H. Large-scale ichthyoplankton and water mass distribution along the South Brazil shelf. PloS ONE, v. 9, n. 3, p. e91241, 2014.

MAFALDA JÚNIOR, P.; RUBÍN, J. P. Interannual variation of larval fish assemblages in the Gulf of Cádiz (SW Iberian Peninsula) in relation to summer oceanographic conditions. Braz. Arch. Biol. Technol., v. 49, n. 2, p. 287-296, 2006.

MAFALDA JÚNIOR, P. O.; SOUZA, C. S.; VELAME, M. P. B. Fish larvae assemblage of a coastal area under influence of petrochemical activities, in Todos os Santos bay, Bahia, Brazil. Aquat. Ecosyst. Health Manag., v. 11, n. 4, p. 457464, 2008.

MAFALDA JÚNIOR, P. O.; SOUZA, C. S.; VELAME, M. P. B.; SOUZA, P. M. M.; PINTO, N. C. T.; SILVA, V. R. F. Oceanografia Biológica: Avaliação espacial e temporal do ictioplâncton, na ZEE do Nordeste Brasileiro. In: HAZIN, F. H. V. (Ed.). Coleção Programa revizee score nordeste. Fortaleza: Martins \& Cordeiro, 2009a. 234 p.

MAFALDA JÚNIOR, P. O.; SOUZA, C. S. Oceanografia Biológica: Estrutura da Comunidade de Larvas de Peixes na ZEE da Região Nordeste do Nordeste do Brasil. Pp. 120-165 In: HAZIN, F. H. V. (Ed.). Coleção Programa revizee score nordeste. Fortaleza: Martins \& Cordeiro, 2009b. 234 p.

MEDEIROS, C.; MACEDO, S. J.; FEITOSA, F. A. N.; KOENING, M. L. Hydrography and phytoplankton biomass and abundance of North-East Brazilian Waters. Arch. Fish. Mar. Res., v. 47, n. 2/3, p. 133-151, 1999.

MEDEIROS, C.; ARAÚJO, M.; FREITAS, I.; ROLLNIC, M. Meteorologia e Sensoriamento Remoto, Oceanografia Física, Oceanografia Química e Oceanografia Geológica: Massas d'água da região oeste do Atlântico Tropical. In: HAZIN, F. H. V. (Ed.). Coleção Programa revizee score nordeste. Fortaleza: Martins \& Cordeiro, 2009. 248 p.
MENEZES, N. A.; BUCKUP, P. A.; FIGUEIREDO, J. L.; MOURA, R. L. Catálogo de Espécies de Peixes Marinhos do Brasil. São Paulo: Museu de Zoologia, 2003, 159 p.

MOSER, H. G.; CHARTER, R. L.; SMITH, P. E.; AMBROSE, D. A.; CHARTER, S. R.; MEYER, C. A.; SANDKNOP, E. M.; WATSON, W. Atlas 32 1994: Distributional atlas of fish larvae in the California current region: Taxa with less than 1000 total larvae, 1951 through 1984. La Jolia: CalCOFI, 1994. 181 p.

MOSER, H. G.; SUMIDA, B.Y. Paralichthyidae: Lefteye flounders and sanddabs. In: MOSER, H. G. (Ed.). Atlas 33 1996: The early stages of fishes in the California Current Region. La Jolia: CalCOFI Atlas, 1996.

NELSON, J. S. Fishes of the World. New York: Jonh Wiley \& Sons, 2006. $601 \mathrm{p}$.

NEUMANN-LEITÃO, S.; GUSMÃO, L. M.; SILVA, T.; NASCIMENTO-VIEIRA, D. A.; SILVA, A. P. Mesozooplankton biomass and diversity in coastal and oceanic waters off North-Eastern Brazil. Arch. Fish. Mar. Res., v. 47, n. 2/3, p. 153-165, 1999.

NEUMANN-LEITÃO, S.; SANT'ANNA, E. M. E.; GUSMÃO, L. M. O.; NASCIMENTO-VIEIRA, D. A.; PARANAGUÁ, M. N.; SCHWAMBORN, R. Diversity and distribution of mesozooplankton in the tropical Southwestern Atlantic. J. Plankton Res., v. 30, n. 7, p. 795-805, 2008.

NOGUEIRA, M. M.; SOUZA, C. S.; MAFALDA JÚNIOR, P. O. The influence of abiotic and biotic factors on the composition of Tetraodontiforms larvae (Teleostei) along the Brazilian Northeast Exclusive Economic Zone $\left(1^{\circ} \mathrm{N}-14^{\circ} \mathrm{S}\right)$. Panamjas, v. 7, p. 10-20, 2012.

NONAKA, R. H.; MATSUURA, Y.; SUZUKI, K. Seasonal variation in larval fish assemblage in relation to oceanographic conditions in the Abrolhos Bank region off eastern Brazil. Fish. Bull., v. 98, p. 767-784, 2000.

OMORI, M.; IKEDA, T. Methods in Marine Zooplankton Ecology. New York: John Wiley and Sons, 1984. 300 p.

PETERSON, R. G.; STRAMMA, L. Upper-level circulation in the South Atlantic Ocean. Prog. Oceanogr., v. 26, n. 1, p. 1-75, 1991.

SABATÉS A. 1990. Changes in the heterogeneity of mesoscale distribution patterns of larval fish associated with a shallow coastal hyaline front. Estuarine, Coastal and Shelf Science 30: 131-140.

SAMPAIO, L. A.; FREITAS, L. S.; OKAMOTO, M. H.; LOUZADA, L. R.; RODRIGUES, R. V.; ROBALDO, R. V. Effects of salinity on Brazilian flounder Paralichthys orbignyanus from fertilization to juvenile settlement. Aquaculture, v. 262, n. 2/4, p. 340-346, 2007.

SCHREIBER, A. M. Review Metamorphosis and early larval development of the flatfishes Pleuronectiformes: an osmoregulatory perspective. Comp. Biochem. Physiol. B, Biochem. Mol. Biol., v. 129, n. 2/3, p. 587-595, 2001.

SILVEIRA, I. C. A.; SCHMIDT, A. C. K.; CAMPOS, E. J. D.; GODOI, S. S.; IKEDA, Y. The Brazil current at east Brazilian coast. Rev. Bras. Oceanogr., v. 48, n. 2, p. 171-183, 2000.

SMITH, P. E.; RICHARDSON, S. L. Standard techniques for pelagic fish eggs and larvae surveys. Fao Fish. Tech. Pap., v. 175, p. 1-100, 1977.

SOUZA, C. S.; LUZ, J. A. G.; MACEDO, S.; MONTES, M. J. F.; MAFALDA JÚNIOR, P. O. Chlorophyll a and nutrient distribution around seamounts and islands of the tropical south- western Atlantic. Mar. Fresh. Res., v. 64, n. 2, p. 168-184, 2013.

STRAMMA, L.; SCHOTT, F. The mean flow field of the tropical Atlantic ocean. Deep Sea Res. Part II Top. Stud. Oceanogr., v. 46, n. 1/2, p. 279-304, 1999. 
TCHERNIA, P. Descriptive Regional Oceanography. Oxford: Pergamon Press, 1980, 253 p.

TER BRAAK, CJF. 1986. Canonical correspondence analysis: a new eigenvector technique for multivariate gradient analysis. Ecology, 67(5): 1167-1179.

TRAVASSOS, P.; HAZIN, F. H. V.; ZAGAGLIA, J. R.; ADVÍNCULA, R.; SCHOBER, J. Thermohaline structure around seamounts and islands off North-Eastern Brazil. Arch. Fish. Mar. Res., v. 47, n. 2/3, p. 211-222, 1999.

VASKE-JÚNIOR, T.; LESSA, R. P.; NÓBREGA, M.; MONTEALEGRE-QUIJANO, S.; MARCANTE SANTANA, F.; BEZERRA, J. L. A. A checklist of fishes from Saint Peter and Saint Paul Archipelago, Brazil. J. Appl. Ichthyol. v. 21, n. 1, p. 75-79, 2005. ZAR, J. H. Biostatistical Analysis. New York: Prentice Hall, 1984. 
